\title{
Gérard-Georges Lemaire, Un habitué al Salon
}

\section{Marco Stupazzoni}

\section{(2) OpenEdition}

\section{Journals}

\section{Edizione digitale}

URL: https://journals.openedition.org/studifrancesi/46067

DOI: 10.4000/studifrancesi.46067

ISSN: 2427-5856

\section{Editore}

Rosenberg \& Sellier

\section{Edizione cartacea}

Data di pubblicazione: 1 octobre 2007

Paginazione: 463

ISSN: 0039-2944

\section{Notizia bibliografica digitale}

Marco Stupazzoni, «Gérard-Georges Lemaire, Un habitué al Salon», Studi Francesi [Online], 152 (LI | II) |

2007, online dal 30 novembre 2015, consultato il 24 novembre 2021. URL: http://

journals.openedition.org/studifrancesi/46067 ; DOI: https://doi.org/10.4000/studifrancesi.46067

Questo documento è stato generato automaticamente il 24 novembre 2021.

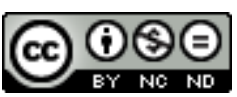

Studi Francesi è distribuita con Licenza Creative Commons Attribuzione - Non commerciale - Non opere derivate 4.0 Internazionale. 


\title{
Gérard-Georges Lemaire, Un habitué al Salon
}

\author{
Marco Stupazzoni
}

\section{NOTIZIA}

GÉRARD-GEORGES LEMAIRE, Un habitué al Salon, in «Art e dossier», gennaio 2003, n. 185, pp.

28-33.

Nonostante le sue assidue frequentazioni, Balzac ebbe con il Salon un rapporto non sempre facile per non dire polemico ed ebbe più di una occasione per esprimere, su quella manifestazione, giudizi radicalmente opposti a quelli dei suoi contemporanei. Tuttavia, fu proprio grazie a quelle frequentazioni che lo scrittore ebbe modo di scoprire alcune opere che lasciarono una traccia duratura nei romanzi della Comédie humaine. L'amore che Balzac ha provato per l'arte in generale e per quella dei suoi contemporanei in particolare «non ha mai avuto smentite» (p. 30) ed è alla pittura che il romanziere ha più volte fatto ricorso «per far risaltare con maggiore consistenza e verosimiglianza agli occhi dei suoi lettori le figure che popolano la sua rappresentazione della Francia della Restaurazione» (p. 31). Si pensi a Raffaello o ai pittori olandesi sino a Girodet, Géricault e Delacroix per non citare che alcuni esempi. Questa intensa relazione con l'arte e, in particolar modo, con la pittura accentuerà la passione di Balzac per il collezionismo soprattutto negli anni in cui la sua relazione con Mme Hanska raggiunse (almeno per lui) il punto più alto per intensità e trasporto. 